\title{
Prevalence of the causative agents of equine piroplasmosis in the South West of The Netherlands and the identification of two autochthonous clinical Theileria equi infections
}

Catherine M. Butler ${ }^{\text {a,b,1 }}$, Marianne M. Sloet van Oldruitenborgh-Oosterbaan ${ }^{a, *}$, Tom A.E Stout ${ }^{\mathrm{a}, \mathrm{c}}$, Johannus H. van der Kolk ${ }^{\mathrm{a}}$, Linda van den Wollenberg ${ }^{\mathrm{d}}$, Mirjam Nielen ${ }^{\mathrm{e}}$, Frans Jongejan ${ }^{\mathrm{b}, \mathrm{f}}$, Arno H. Werners ${ }^{\mathrm{a}, 2}$, Dirk J. Houwers ${ }^{\mathrm{g}}$

${ }^{a}$ Department of Equine Sciences, Utrecht University, Yalelaan 114, 3584 CM, Utrecht, The Netherlands

${ }^{b}$ Utrecht Centre for Tick-borne Diseases, Faculty of Veterinary Medicine, Utrecht University, Yalelaan 1, 3508 TD, Utrecht, The Netherlands.

${ }^{c}$ Department of Production Animal Sciences, Faculty of Veterinary Science, University of Pretoria, Private Bag X04, Onderstepoort 0110, South Africa.

${ }^{d}$ DAP Bodegraven, Zuidzijde 63, 2411 RT Bodegraven, The Netherlands

${ }^{e}$ Department of Farm Animal Health, Faculty of Veterinary Medicine, Utrecht University, Yalelaan 7, 3584 CL Utrecht, The Netherlands

${ }^{f}$ Department of Veterinary Tropical Diseases, Faculty of Veterinary Science, University of Pretoria, Private Bag X04, Onderstepoort 0110, South Africa

${ }^{g}$ Veterinary Microbiological Diagnostic Centre, Department of Infectious Diseases and Immunology, Faculty of Veterinary Medicine, Utrecht University, PO Box 80.165, 3508 TD Utrecht, The Netherlands.

*Corresponding author. Tel.: +31302531350.

E-mail address: m.sloet@uu.nl (M. Sloet).

${ }^{1}$ Current address: Large Animal Academic Programme School of Veterinary Medicine, St. George University, True Blue, Grenada WI.

${ }^{2}$ Current address: Anatomy, Physiology and Pharmacology Academic Programme, School of Veterinary Medicine, St. George University, True Blue, Grenada WI.

\section{Abstract}

Equine piroplasmosis (EP) has not been considered indigenous in The Netherlands.

However, following detection of an apparently indigenous subclinical Babesia caballi infection in a horse on Schouwen-Duiveland (an island in the Zeeland Province), a survey was undertaken between May and September 2010 to assess the prevalence of the causative agents of EP in the South West of The Netherlands. Blood samples from 300 randomly selected horses were tested for specific antibodies against Theileria equi and B. caballi using an indirect fluorescence antibody test (IFAT), and for parasite DNA using a specific polymerase chain reaction combined with reverse line blotting (PCR-RLB). 
Twelve of the horses (4\%) were seropositive for EP. Of these, nine $(75 \%)$ were positive (titre $\geq 1: 160)$ for $B$. caballi alone and three (25\%) were also positive for $T$. equi. PCR-RLB detected T. equi DNA in five horses (1.6\%), two of which were seronegative. Four $(1.3 \%)$ of the positive horses (three positive for T. equi and one for both B. caballi and T. equi) were considered truly indigenous.

During the study, two indigenous ponies from a farm situated outside the sampling area were diagnosed with acute clinical piroplasmosis characterized by severe anaemia and pyrexia. Blood smears showed T. equi-like inclusions in red blood cells, and T. equi infection was confirmed in both ponies by PCR-RLB. The initial subclinical B. caballi infection, the survey results and the two acute clinical EP cases confirmed the autochthonous transmission of $B$. caballi and T. equi infections in The Netherlands.

Keywords: Horse, Piroplasmosis, Babesia caballi, Theileria equi, PCR-RLB

\section{Introduction}

Equine piroplasmosis (EP) is an important tick-borne protozoan disease that poses a serious threat to the horse industry and has important implications for the international movement of horses (Friedhoff et al., 1990). The disease is caused by Babesia caballi and/or Theileria equi and is endemic in many tropical and subtropical areas (de Waal, 1992). Since EP can occur in any region or environment where horses are exposed to vector ticks, horses in countries with a moderate climate can also be affected (Mehlhorn and Schein, 1998). Relocation of carrier horses and infected ticks by international transport is a potential means of spreading the infection. The expansion of permissive tick vectors to hitherto non-endemic countries and the 
changes in habitat for both ticks and wildlife species as a result of climate change are other promoting factors (Sreter et al., 2005). Ticks capable of acting as vectors for B. caballi and T. equi include those belonging to the genera Dermacentor, Hyalomma and Rhipicephalus (Uilenberg, 2006).

According to the World Organisation for Animal Health (OIE) Manual (2010), The Netherlands is considered free of autochthonous EP. However, the recent discovery of resident Dermacentor reticulatus populations (Nijhof et al., 2007), combined with a subclinical B. caballi infection in a horse that had never left The Netherlands, prompted investigation of the actual prevalence of $B$. caballi and T. equi.

The aims of this study were to determine the prevalence of T. equi and B. caballi infections in horses in the area where the initial subclinical B. caballi infection occurred. In addition, we report the first confirmed acute autochthonous $T$. equi infections in indigenous ponies in The Netherlands.

\section{Materials and methods}

Case that prompted the study

The subclinical case that prompted the present study involved a 12-year-old Dutch Warmblood gelding presented to a referral clinic (DAP Bodegraven) for treatment of a massive tick infestation with extensive skin swelling following a ride in a forest on Schouwen-Duiveland (an island in the Province of Zeeland) in July 2009. The skin swelling was treated with a combination of a non-steroidal anti-inflammatory drug (flunixin meglumine, $1 \mathrm{mg} / \mathrm{kg}$ body 
weight $[\mathrm{BW}]$ intravenously [IV]) and an antibiotic (oxytetracycline, $6.6 \mathrm{mg} / \mathrm{kg} \mathrm{BW}$, every $12 \mathrm{~h}$

IV for 7 days). The infestation of the limbs and ventral abdomen was so extensive that an acaricidal fluid (fipronil, Frontline, Merial) was sprayed on the affected areas. Most ticks were identified as engorged Ixodes ricinus nymphs, but there were simply too many ticks to identify all of them. Thus, species other than I. ricinus, which is not considered a vector of EP, may have been present.

\section{Table 1}

Haematological results (references values in column headings); packed cell volume (PCV), white blood cell count (WBC) and thrombocyte count (PLT). Blood smear results; T. equi or B. caballi inclusions visible in red blood cells. Serological results; indirect fluorescence antibody test (IFAT) for T. equi and B. caballi (positive if titre $\geq 1: 160$ ), and molecular (polymerase chain reaction combined with reverse line blotting [PCR-RLB]: - negative; + positive) results of blood samples collected from a subclinical B. caballi-infected horse (KWPN) and two T. equiinfected ponies (pony A and pony B) with clinical symptoms of equine piroplasmosis. All three horses were indigenous to The Netherlands.

\begin{tabular}{||c||c|c|c|c|c|c|c||}
\hline Horse & Date & $\begin{array}{l}\text { PCV } \\
(0.32-0.50 \\
\mathrm{L} / \mathrm{L})\end{array}$ & $\begin{array}{l}\text { WBC } \\
(7-12 \\
\mathrm{g} / \mathrm{L})\end{array}$ & $\begin{array}{l}\text { PLT } \\
(75-300 \\
\mathrm{g} / \mathrm{L})\end{array}$ & Blood smear & IFAT & PCR-RLB \\
\hline \hline KWPN & 20 June 2009 & 0.39 & 6.8 & 74 & - & - & $+($ B. caballi $)$ \\
\hline & 29 July 2009 & 0.39 & 5.5 & 50 & - & $1: 160$ & - \\
\hline Pony A & 28 July 2010 & 0.11 & 24.5 & 39 & $+($ T. equi $)$ & $1: 640$ & $+($ T. equi $)$ \\
\hline Pony B & 22 July 2010 & 0.27 & 6.6 & 222 & - & - & - \\
\hline & 29 July 2010 & 0.15 & 11.7 & 108 & $+($ T. equi $)$ & $1: 320$ & $+($ T. equi $)$ \\
\hline
\end{tabular}

On presentation, a Giemsa-stained blood smear was negative for inclusions, and an indirect fluorescence antibody test (IFAT) was negative for B. caballi IgG. However, a polymerase chain reaction combined with reverse line blotting (PCR-RLB) was positive for $B$. caballi DNA. Blood taken from the horse 6 weeks later was negative for B. caballi parasites in both the thin blood smear and PCR-RLB but was positive for B. caballi antibodies in the IFAT (Table 1). In view of this subclinical case, the Dutch Ministry of Economic Affairs, Agriculture and Innovation) supported a seroprevalence survey in Zeeland to evaluate the present situation with regard to EP. During the course of the investigation, one of the authors was consulted about 
two indigenous ponies in the south of the country that appeared to be suffering from acute clinical EP. At present, little information is available on the epidemiology of EP in North Western Europe.

Sample collection

To detect a $1 \%$ incidence of infection with a certainty of $95 \%$ in a population estimated at $5000-10000$ horses living in the 'high risk area' where the subclinical EP had been diagnosed, it was calculated that a minimum of 300 animals needed to be tested (Win Episcope, Risk-based sampling) (Fig. 1). For this we used the formula:

$n=\left[1-(\alpha)^{1 / \mathrm{D}}\right][N-(\mathrm{D}-1) / 2]$

where $n=$ required sample size; $\alpha=1-$ confidence level $(0.05) ; \mathrm{D}=$ estimated minimum number of diseased animals in population; $N=$ population size) (Dohoo et al., 2010).

Between May and August 2010, jugular vein blood samples were collected into EDTA and serum tubes from 300 horses. Apparently healthy horses that were either privately owned or owned by a riding school were selected and sampled based on (1) the owner's willingness to cooperate, (2) the horse having lived in the area for at least 1 year and (3) the horse having access to pasture and/or being used for outdoor recreation.

Blood sampling of client-owned horses for diagnostic purposes is not considered animal experimentation under Dutch law; this was confirmed by Utrecht University's Animal Ethical Committee for this specific study. 


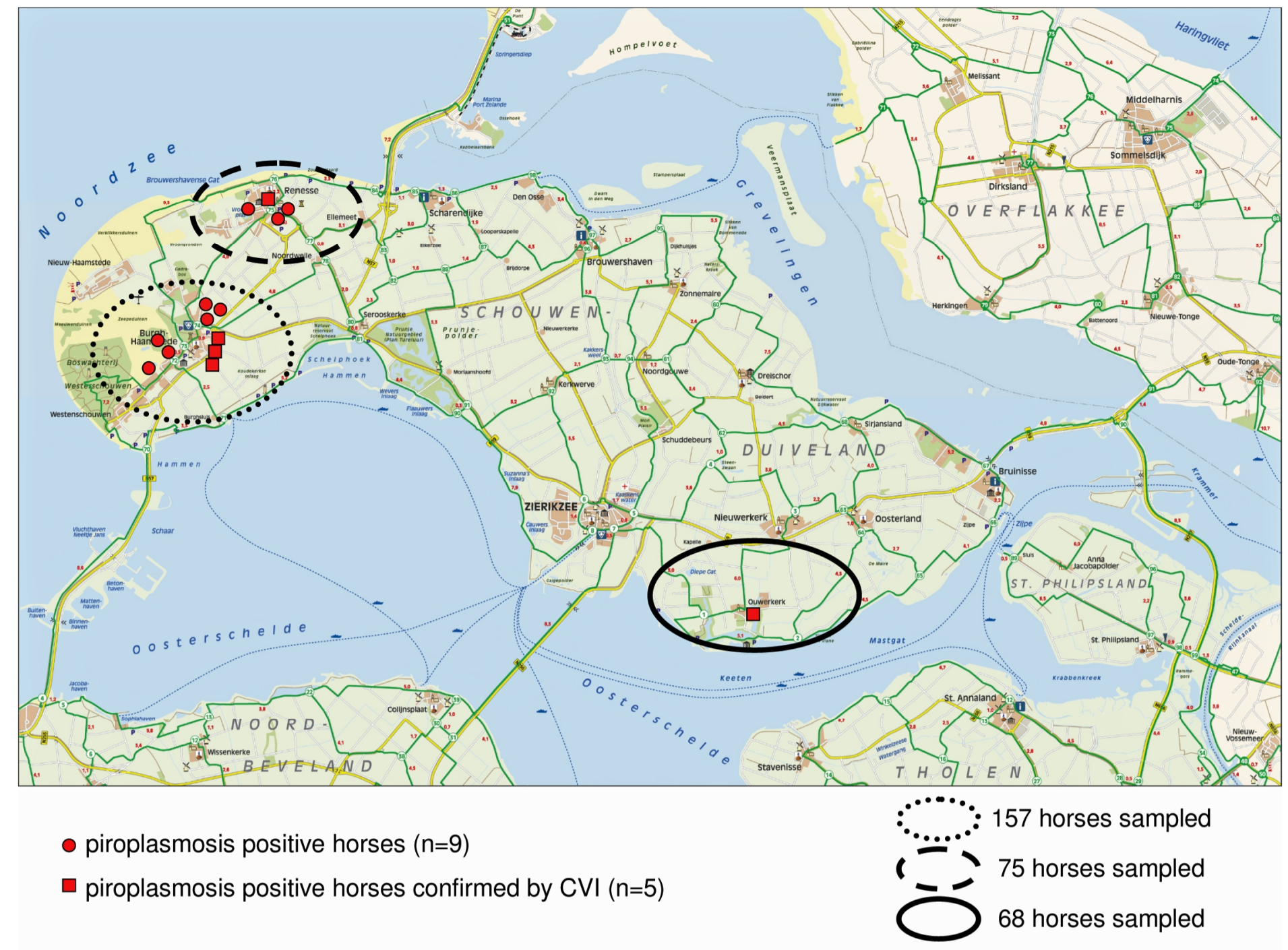

Figure 1. A map of Schouwen-Duiveland (Zeeland, The Netherlands) including the locations of both sampled and piroplasma positive horses. 
Samples were placed and kept on ice immediately after collection and subsequently stored at $4{ }^{\circ} \mathrm{C}$ for a maximum of $18 \mathrm{~h}$ before processing. After haematological screening, the remaining EDTA blood was stored at $-20^{\circ} \mathrm{C}$ until DNA extraction was performed. Serum was stored at $-20^{\circ} \mathrm{C}$ until the serological tests were performed. Seven stallions, 147 geldings and 146 mares ranging in age from 12 weeks to 25 years and representing various breeds (Dutch Warmblood, Quarter horse, Paint horse, Merens, Friesian, Icelandic, Fjord, Shetland pony, Welsh pony, Falabella, Standardbred, Thoroughbred, Belgian Draft, Irish Cob, Arab) were included in the study. Since it is often difficult to establish whether horses are truly autochthonous and have not travelled to another country at some point in their lives, it was decided to only attempt to trace the full background and movements of horses that were EP positive.

\section{Haematology}

Haematology was used to determine whether (in the group of 300 apparently healthy horses included in the survey) positivity for piroplasmosis had an influence on packed cell volume, white blood cell count, or thrombocyte count. All 300 EDTA samples were therefore analysed on the day of sampling using a Medonic Haematology Analyzer.

IFAT

Samples were screened for antibodies against $T$. equi and $B$. caballi using a standard IFAT protocol, as described by Madden and Holbrook (1968). Bound equine IgG antibodies were detected using a fluorescein isothiocyanate-conjugated rabbit anti-horse secondary antibody (RAHo/IgG(H + L)FITC; Nordic Immunology). All samples were screened at a starting dilution 
of 1:80 in phosphate-buffered saline ( $\mathrm{pH} 7.2)$, as described in the manufacturer's protocol. Positive samples were subsequently analysed to determine the titre. Antibody titres were categorized into three groups: 1:80,1:160 and >1:320. Any sample showing fluorescence at a dilution of $\geq 1: 160$ was considered positive. Positive and negative controls were included in each run.

DNA extraction

DNA was extracted from EDTA blood using the QIAamp DNA mini kit (Qiagen) as described in the manufacturer's protocol.

\section{PCR amplification and reverse line blot (RLB) hybridization}

The primers RLB-F2 (5'-GAC ACA GGG AGG TAG TGA CAA G-3') and RLB-R2 (5'biotin-CTA AGA ATT TCA CCT CTG ACA GT-3') were used to amplify the V4 hyper-variable region of the piroplasmid $18 \mathrm{~S}$ rRNA gene, and the PCR products were subsequently subjected to RLB hybridization as described previously (Nijhof et al., 2005). Positive and negative controls were included in each run.

\section{Clinical EP cases}

Two pregnant ponies (A and B; aged 18 and 20 years, respectively), housed together and acquired 2 and 5 months previously (from different parts of The Netherlands) for the purpose of commercial plasma collection, were presented to a local practitioner with signs of lethargy, anorexia and pyrexia. Blood was collected in EDTA and serum tubes. Because the acute signs suggested EP, the samples were analysed for the presence of $T$. equi and B. caballi by 
microscopic examination of stained thin blood smears and by serology (IFAT) and molecular testing (PCR-RLB). Blood collected (and stored with EDTA at $4{ }^{\circ} \mathrm{C}$ ) from pony B approximately 7 days prior to clinical signs was also tested. Once piroplasmosis was confirmed, the ponies received a blood transfusion, and treatment with imidocarb dipropionate ( $4 \mathrm{mg} / \mathrm{kg}$ BW every 72 $\mathrm{h}$ intramuscularly) was recommended.

\section{Statistical evaluation}

All data are given as absolute numbers, as percentages or as means \pm standard deviations. Statistical evaluation of the blood parameters was performed using a two-sample $t$ test (software used: R, A Language and Environment for Statistical Computing, R Development Core Team R Foundation for Statistical Computing, 2010). $P<0.05$ was considered to be statistically significant.

\section{Results}

Survey

Of the 300 horses included in the survey, 12 (4\%) tested seropositive for EP (Table 2). Of these, nine ( $3 \%)$ were seropositive (titre $\geq 1: 160)$ for $B$. caballi and three (1\%) were positive for both $B$. caballi and T. equi. In addition five horses (1.6\%) tested positive for T. equi DNA, although only three had T. equi antibody titres (Table 2). Babesia caballi DNA was not detected by PCR-RLB, but one horse (horse 123) was positive for the Babesia catch-all genus probe used in conjunction with a $B$. bovis probe (not included in Table 2). In samples that were positive for EP, the platelet count was lower than in the negative samples $(P=0.025$; Table 3$)$. 


\section{Table 2}

Results of an indirect fluorescence antibody test (IFAT) for T. equi and B. caballi (positive if titre $\geq 1: 160$ ) and/or polymerase chain reaction combined with reverse line blotting (PCR-RLB; negative; + positive) for T. equi and/or B. caballi for the 14 horses that tested positive for piroplasmosis in a survey of 300 randomly selected horses in the South West of The Netherlands.

* Also tested by the Central Veterinary Institute in Lelystad, the national reference laboratory, and reported to the OIE by the Chief Veterinary Officer of The Netherlands on February 16, 2011 together with the two clinical pony cases (WAHID 2011).

\begin{tabular}{||l|l|l|l|l|l|l||}
\hline \hline $\begin{array}{l}\text { Horse } \\
\text { number }\end{array}$ & $\begin{array}{l}\text { IFAT } \\
\text { T. equi }\end{array}$ & $\begin{array}{l}\text { IFAT } \\
\text { B. caballi }\end{array}$ & PCR-RLB & $\begin{array}{l}\text { Age } \\
\text { years })\end{array}$ & Breed & $\begin{array}{l}\text { Origin of the horse according } \\
\text { information of the owner }\end{array}$ \\
\hline \hline $5^{*}$ & $1: 640$ & $1: 160$ & $+($ T. equi $)$ & 11 & Merens & Visited France \\
\hline 7 & - & - & $+($ T.equi) & 13 & Merens & Visited France \\
\hline $10^{*}$ & $1: 5120$ & $1: 160$ & $+($ T. equi) & 20 & Thoroughbred & Imported from Russia 16 years ago \\
\hline $12^{*}$ & - & $1: 160$ & - & 16 & Hackney & The Netherlands, no travel last 9 years \\
\hline $17^{*}$ & $1: 640$ & $1: 160$ & $+($ T. equi $)$ & 8 & Pony unknown & The Netherlands, no travel \\
\hline 24 & - & $1: 160$ & - & 18 & Dutch Warmblood & The Netherlands, no clear history \\
\hline 37 & - & $1: 160$ & - & 16 & Dutch Warmblood & The Netherlands, no clear history \\
\hline 61 & - & $1: 160$ & - & 25 & Dutch Warmblood & The Netherlands, no clear history \\
\hline 92 & - & $1: 160$ & - & 16 & Dutch Warmblood & The Netherlands, no clear history \\
\hline 111 & - & $1: 160$ & - & 15 & Shetland pony & The Netherlands, no travel last 9 years \\
\hline 114 & - & - & $+(T . e q u i)$ & 25 & Dutch Warmblood & The Netherlands, no travel last 19 years \\
\hline $142^{*}$ & - & $1: 160$ & - & 2 & Shetland pony & The Netherlands, no travel \\
\hline 210 & - & $1: 160$ & - & 11 & Belgian draft horse & The Netherlands, no travel \\
\hline 236 & - & $1: 160-320$ & - & 5 & Belgian draft horse & The Netherlands, no travel \\
\hline
\end{tabular}

\section{Clinical cases}

Haematological assessment of the two ponies (A and B) that presented with signs suggesting acute piroplasmosis revealed marked anaemia in both cases and a marked thrombocytopenia for pony A (Table 1). Microscopic examination of thin blood smears revealed round to pear-shaped bodies and an occasional 'Maltese cross' inside the red blood cells, indicating T. equi organisms (Fig. 2). No antibodies to T. equi were detected and PCR-RLB was negative for T. equi in blood collected from 
pony B 1 week before clinical signs were apparent. However, during the period in which the ponies showed clinical signs, both T. equi antibodies and DNA (via PCR-RLB) were detected in blood from both animals (Table 1).

Table 3

Haematological parameters for 300 randomly selected horses divided by piroplasma status (positive or negative horses). Values are shown as means ( \pm standard deviation).

\begin{tabular}{|l|c|c|c|c||}
\hline & All horses in survey & $\begin{array}{l}\text { Piroplasmosis positive } \\
\text { (IFAT or PCR-RLB) }\end{array}$ & $\begin{array}{c}\text { Piroplasmosis negative } \\
\text { (IFAT and PCR-RLB) }\end{array}$ & $\begin{array}{l}\text { Reference } \\
\text { values }^{\mathrm{b}}\end{array}$ \\
\hline & $n=300$ & $n=14$ & $n=286$ & \\
\hline PCV (L/L) & $0.33 \pm 0.05$ & $0.36 \pm 0.02$ & $0.33 \pm 0.00$ & $0.32-0.50$ \\
\hline WBC (G/L) & $8.2 \pm 2.1$ & $8.2 \pm 0.6$ & $8.2 \pm 0.1$ & $7-10$ \\
\hline PLT (G/L) & $94 \pm 33$ & $79 \pm 8^{\mathrm{c}}$ & $95 \pm 2$ & $75-300$ \\
\hline
\end{tabular}

${ }^{\mathrm{a}}$ IFAT, indirect fluorescence antibody test; PCR-RLB, polymerase chain reaction combined with reverse line blotting.

${ }^{\mathrm{b}}$ Reference values from Sellon and Wise (2010).

${ }^{c}$ A statistically significant reduction in thrombocyte counts in piroplasmosis-positive horses compared to piroplasmosis-negative horses $(P=0.025)$.

\section{Discussion}

Blood analysis and serological and molecular testing demonstrated the presence of $T$. equi in two indigenous ponies and B. caballi in one indigenous Dutch Warmblood horse. The subclinical course of infection in the latter animal may have been due to the immediate prophylactic administration of oxytetracycline in an attempt to curb the potential sequelae of the severe tick infestation; oxytetracycline has been shown to exhibit an inhibitory effect on T. equi sporozoites cultured in vitro and on Babesia divergens replication in cattle (Taylor et al., 1986) if administered early during infection (Zweygarth et al., 1984). 


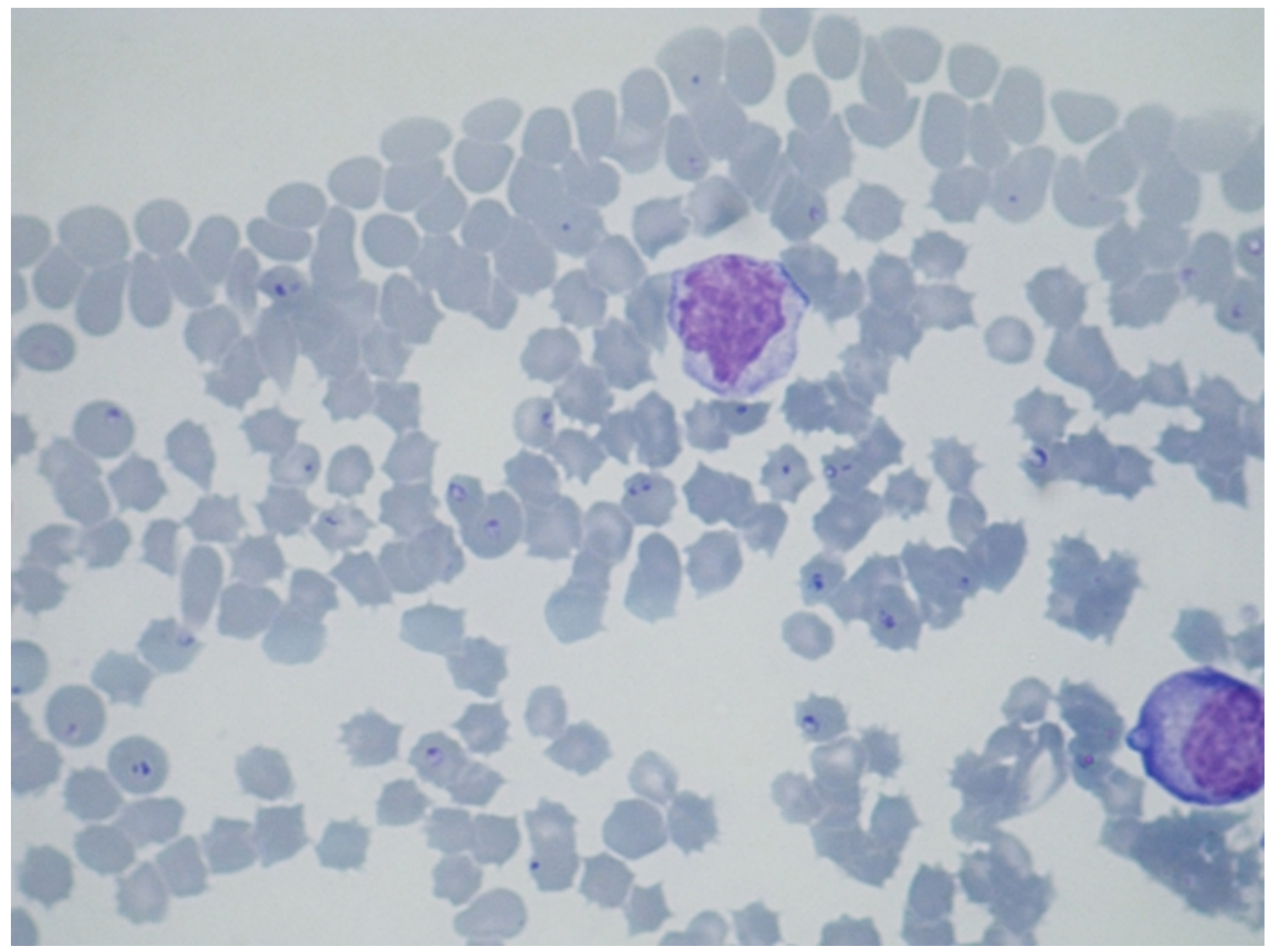

\section{Fig. 2.}

Theileria equi parasites in red blood cells as visualized by Giemsa staining of a thin blood smear from pony A.

With respect to the acute $T$. equi cases described in this study, the owner stated that the two ponies had been on the premises for only 2 months (pony B) and 5 months (pony A), respectively, having been purchased from different areas of The Netherlands (Provinces of Gelderland and Friesland, respectively). Both ponies showed clinical signs suggestive of acute piroplasmosis. Importantly, while specific antibodies were not detected in pony B at first presentation, a T. equi titre of 1:320 was detected by IFAT 7 days later, indicating that pony B had acquired the infection at its new location in The Netherlands. Pony A showed clinical signs 
indicative of piroplasmosis 1 week before pony B. Unfortunately, no initial blood sample was available from pony A.

Both ponies were pregnant and used for commercial plasma collection so it is possible that the immunosuppressant effects of pregnancy or the stress of pregnancy and/or plasma collection activated a dormant infection leading to clinical disease. In this respect, it cannot be excluded that pony A was a T. equi carrier and experienced reactivation, after which it became a reservoir for transmission to pony $\mathrm{B}$, either via a tick vector or iatrogenically (in this case as a result of blood collection procedures). The latter mode of transmission is unlikely, however, because new disposable catheters were used for each horse as a standard procedure. It is therefore possible that both ponies were infected via $D$. reticulatus ticks present in the surrounding environment. Dermacentor reticulatus ticks are distributed in Europe by animals travelling to and from endemic areas, with the majority originating from Southern Europe, where D. reticulatus is well established (Estrada-Pena et al., 2004). In theory, several wildlife species including migrating birds could also play a role in tick distribution.

The results of our survey show that although piroplasma infections are found in horses imported into The Netherlands, the prevalence of seropositive or DNA positive horses, in both the indigenous and imported horse populations, is still relatively low. Most studies on the prevalence of T. equi and B. caballi have been conducted in Southern Europe where the infection is endemic (Camacho et al., 2005; Leblond et al., 2005; Kouam et al., 2010; Moretti et al., 2010). Little information is available on the prevalence and possible emergence of EP in North Western Europe, with published data only available from Germany and Switzerland where 
seroprevalences of $5.6 \%$ and $4.4 \%$ T. equi and $1.2 \%$ and $1.5 \%$ B. caballi, respectively, have been reported (Boch, 1985; Sigg et al., 2010). Several clinical cases of EP have been recorded in Belgium (Mantran et al., 2004) but no information is available on the seroprevalence of EP in that horse population.

The overall seroprevalence in the present study is of a similar magnitude to those reported in Switzerland and Germany. Furthermore, the seroprevalence for B. caballi in the current study was higher than for T. equi, which is also in line with both other reports. While antibody titres indicate past infections of unknown age, positive PCR-RLB results demonstrate current active parasite infestation. Positive PCR-RLB results for T. equi in the peripheral blood of two indigenous and three imported horses are reasons for concern with regard to the spread of this pathogen in The Netherlands; horses are considered to be the primary reservoir for T. equi (Allsopp et al., 2007; Ueti et al., 2008) and established populations of D. reticulatus are now present in The Netherlands (Nijhof et al., 2007).

Two of the five horses that tested positive for T. equi in the PCR-RLB did not have an antibody titre when examined by IFAT, and it is therefore likely that they had been infected relatively recently. An interesting finding in this survey was the detection of $B$. bovis DNA via PCR-RLB performed on blood collected from horse 123. This particular horse was apparently healthy, and its haematological parameters were within the normal range. Even though it has been reported once previously (Criado et al., 2006), the significance of $B$. bovis DNA in a horse is unclear. 
Clinicopathological abnormalities in horses with a T. equi and/or a B. caballi infection may include a reduced red blood cell count, platelet count and haemoglobin concentration (de Waal, 1992). The significantly lower platelet count in the piroplasmosis positive horses in the present study is therefore consistent with (sub)clinical piroplasmosis.

\section{Conclusions}

This study confirmed that autochthonous EP occurs in The Netherlands, albeit sporadically. With the apparent establishment of indigenous D. reticulatus populations (Nijhof et al., 2007) and unrestricted importation of horses from piroplasmosis endemic areas, the chance of encountering clinical EP cases in The Netherlands is likely to increase and veterinarians should therefore consider this disease in the differential diagnosis for anaemic horses, even if the animals have never left the country.

\section{Acknowledgements}

This research was partly funded by the Dutch Ministry of Agriculture. We thank the cooperating local veterinarians, D. de Wijs, K. Buth and R. van der Linde, whose efforts made this study possible. We also thank J. Balk and M. van Leeuwen (Department of Clinical Sciences of Companion Animals, Utrecht University) for laboratory assistance. 


\section{Conflict of interest statement}

None of the authors of this paper has a financial or personal relationship with other persons or organisations that could inappropriately influence or bias the content of the paper.

\section{References}

Allsopp, M.T., Lewis, B.D., Penzhorn, B.L., 2007. Molecular evidence for transplacental transmission of Theileria equi from carrier mares to their apparently healthy foals. Veterinary Parasitology 148, 130-136.

Boch, J., 1985. Babesia infections in horses, cattle and dogs in southern Germany. Tierärztliche Praxis 1, 3-7.

Camacho, A.T., Guitian, F.J., Pallas, E., Gestal, J.J., Olmeda, A.S., Habela, M.A., Telford, S.R. 3rd, Spielman, A., 2005. Theileria (Babesia) equi and Babesia caballi infections in horses in Galicia, Spain. Tropical Animal Health and Production 37, 293-302.

Criado, A., Martinez, J., Buling, A., Barba, J.C., Merino, S., Jefferies, R., Irwin, P.J., 2006. New data on epizootiology and genetics of piroplasms based on sequences of small ribosomal subunit and cytochrome b genes. Veterinary Parasitology 142, 238-247.

de Waal, D.T., 1992. Equine piroplasmosis: a review. British Veterinary Journal 148, 6-14.

Dohoo, I., Martin, W., Stryhn, H., 2010. Veterinary epidemiologic research, second Ed. VER Inc., Charlottetown, Canada, pp. 54-55.

Estrada-Pena, A., Quiez, J., Sanchez Acedo, C., 2004. Species composition, distribution, and ecological preferences of the ticks of grazing sheep in North-Central Spain. Medical and Veterinary Entomology 18, 123-133.

Friedhoff, K.T., Tenter, A.M., Muller, I., 1990. Haemoparasites of equines: impact on international trade of horses. Scientific and Technical Review 9, 1187-1194.

Kouam, M.K., Kantzoura, V., Gajadhar, A.A., Theis, J.H., Papadopoulos, E., Theodoropoulos, G., 2010. Seroprevalence of equine piroplasms and host-related factors associated with infection in Greece. Veterinary Parasitology 169, 273-278.

Leblond, A., Pradier, S., Pitel, P.H., Fortier, G., Boireau, P., Chadoeuf, J., Sabatier, P., 2005. An epidemiological survey of equine anaplasmosis (Anaplasma phagocytophilum) in Southern France. Scientific and Technical Review 24, 899-908. 
Madden, P.A., Holbrook, A.A., 1968. Equine piroplasmosis: indirect fluorescent antibody test for Babesia caballi. American Journal of Veterinary Research 29, 117-123.

Mantran, A., Votion, D.M., Amory, H. 2004. Piroplasmosis: a problem in Belgium? In: Proceedings of the Annual Congress Belgian Equine Practitioners Society, Liege, Belgium. $\nleftarrow \mathrm{http}: / / \mathrm{www}$. ivis.org/proceedings/BEPS/2004/Amory_nl/ivis.pdf (accessed 3 September 2011).

Mehlhorn, H., Schein, E., 1998. Redescription of Babesia equi Laveran, 1901 as Theileria equi Mehlhorn, Schein 1998. Parasitology Research 84, 467-475.

Moretti, A., Mangili, V., Salvatori, R., Maresca, C., Scoccia, E., Torina, A., Moretta, I., Gabrielli, S., Tampieri, M.P., Pietrobelli, M., 2010. Prevalence and diagnosis of Babesia and Theileria infections in horses in Italy: a preliminary study. The Veterinary Journal $184,346-350$.

Nijhof, A.M., Bodaan, C., Postigo, M., Nieuwenhuijs, H., Opsteegh, M., Franssen, L., Jebbink, F., Jongejan, F., 2007. Ticks and associated pathogens collected from domestic animals in The Netherlands. Vector-Borne and Zoonotic Diseases 7, 585-595.

Nijhof, A.M., Pillay, V., Steyl, J., Prozesky, L., Stoltsz, W.H., Lawrence, J.A., Penzhorn, B.L., Jongejan, F., 2005. Molecular characterization of Theileria species associated with mortality in four species of African antelopes. Journal of Clinical Microbiology 43, 5907-5911.

Sellon, D.C., Wise, L.N., 2010. Disorders of the hemapoetic system. In: Equine Internal Medicine, Third Ed. Saunders Elsevier, St. Louis, MO, USA, pp. 230-276.

Sigg, L., Gerber, V., Gottstein, B., Doherr, M.G., Frey, C.F., 2010. Seroprevalence of Babesia caballi and Theileria equi in the Swiss horse population. Parasitology International 59, 313-317.

Sreter, T., Szell, Z., Varga, I., 2005. Spatial distribution of Dermacentor reticulatus and Ixodes ricinus in Hungary: evidence for change? Veterinary Parasitology 128, 347-351.

Taylor, S.M., Elliott, C.T., Kenny, J., 1986. Inhibition of Babesia divergens in cattle by oxytetracycline. Veterinary Record 118, 98-102.

Ueti, M.W., Palmer, G.H., Scoles, G.A., Kappmeyer, L.S., Knowles, D.P., 2008. Persistently infected horses are reservoirs for intrastadial tick-borne transmission of the apicomplexan parasite Babesia equi. Infection and Immunity 76, 3525-3529.

Uilenberg, G., 2006. Babesia - a historical overview. Veterinary Parasitology 138, 3-10. 
WAHID Weekly disease reports OIE - February 16, 2011 a

http://web.oie.int/wahis/public.php?page=weekly_report_index\&admin $=0$ (accessed 15 May 2011).

World Organisation for Animal Health (OIE) $\nleftarrow$ http://www.oie.int/ (accessed 15 May 2011).

Zweygarth, E., Ahmed, J.S., Rehbein, G., 1984. The effect of halofuginone, Wellcome 993 C, oxytetracycline, and diminazene diaceturate on Babesia equi-infected lymphoblastoid cell cultures. International Journal for Parasitology 70, 542-544. 